ISBN 978-93-84422-77-6

3rd International Conference on Innovations in Civil, Architectural and Transport Engineering

(ICATE-2017)

Dubai (UAE) May 10-11, 2017

\title{
Identifying Scope for Future Research on Urban Greening in India-AComparative Perspective with Global Greening Initiatives
}

\author{
Aabshar U.K. Imam ${ }^{1}$ and Uttam Kumar Banerjee ${ }^{2}$ \\ ${ }^{1}$ Ex-Research Scholar, Department of Architecture and Regional Planning, Indian Institute of Technology \\ Kharagpur, India \\ ${ }^{2}$ Professor, Department of Architecture and Regional Planning, Indian Institute of Technology Kharagpur, India
}

\begin{abstract}
Urban green spaces constitute an integral component of sustainable urban surroundings. While controlled population density and higher capital investment ensure a greener ambience in the developed countries, developing countries like India face environmental crisis due to presence of urban heat islands (UHIs), waning of green cover, increase in carbon emissions, and air pollution. The Indian National Action Plan on Climate Change emphasises the national missions of 'enhanced energy efficiency', and 'green India'. However, there is a lack of adequate research investigating the role of green spaces in the sustainable development of urban India. This study aims at comparing the general trend of global scientific research, and the research in India to find out the areas needing impetus and improvement.It is also expected to assist city planners and town planning authorities in the development of green cities
\end{abstract}

Keywords: Urban green space; sustainable development; India

\section{Introduction}

The burgeoning global population and the rapid pace of urbanisation have depleted the proportion of globalurban green cover. India has emerged as a major economic power during the last decade. However, the progress of Indian economy is largely threatened by the impact of climate change. Adequate percentage of urban green cover is a pre-requisite for sustainable development. Green spaces play a multifaceted role in our day to day lives.They provide essential zones for recreation, regulate the thermal environment, reduce level of atmospheric pollution, and encourage social bonding besides fostering a spirit of community living. Although urban green spaces have garnered much recognition in the western world, it has been only in the recent times that importance has been attached to green spaces in developing countries like India. Although the Indian National Action Plan on Climate Change emphasises the need for green India, little research has been devoted to study the benefits of green spaces in Indian cities.

The present study reviews articles published in scientific journals to provide a broad overview of the benefits of green spaces. A comparison is then attemptedbetween the research conducted in India and those conducted elsewhere (Refer Table 1) to identify the probable areas of future research in India, and also highlight the best practices pioneered in India which can be replicated in other developing countries. This study is also expected to assist city planners and town planning authorities in developing green cities. The benefits of green spaces have beencategorised(1)under the following sub-headings: environmental benefits, mental and physical benefits, social benefits, and economic benefits. It should be noted that a number of other globalresearch studies are available, but since the objective of this study is to provide a broad overview, only few examples have been cited here. 


\section{Environmental Benefits}

Urban greenery enhances indoor and outdoor thermal comfort besides providing air conditioning energy savings due to maintainance of a cooler environment primarily through:

\subsection{Removal of Atmospheric Pollutants}

Vegetation helps in the removal of atmospheric pollutants through the absorption of gaseous pollutants (2), dry deposition of suspended particulate emissions (3), bioaccumulation of heavy metal air pollution(4), and daytime photosynthetic assimilation of $\mathrm{CO} 2$. Street trees have been observed to reduce levels of suspended particulate matter and contributed to 65\% reduction in SO2 levels in Bengaluru, India(5). High swathes of green cover in the Indian cities of Gandhinagar (green space of $160 \mathrm{~m} 2$ per capita) (6), and Chandigarh (green space of $55 \mathrm{~m} 2$ per capita) (7), appear to reduce $\mathrm{SO} 2$ and NOx concentrations. Interestingly, although Gandhinagar is a major SO2 and NOx emitting district in India (8), concentrations of SO2 (3-37 $\mu \mathrm{g} / \mathrm{m} 3)$ and NOx $(5-34 \mu \mathrm{g} / \mathrm{m} 3)$ remain within permissible limits around the Gandhinagar Thermal Power Plant (9). Atmospheric pollutants are known to absorb and re-radiate heat radiation from urban surfaces thus adding to urban heating (10). Therefore, reduction in atmospheric pollution levelsthrough trees helps to cool the urban environment and thereby reducesthe cooling requirements.

\subsection{Passive Cooling of the Ambient Environment}

Vegetative interfaces induce passive cooling of the environment primarily through shading and evapotranspiration. A row of Kaizukahort trees planted close to the western wall of a building in Fukuoka, Japan intercepted $95 \%$ of the incident solar radiation thus, shading the building against afternoon sun(11). Tree shade reduced residential cooling energy savings in Sacramento, USA by $30 \%$ (12). A decrease of $72 \%$ was estimated in the cooling energy demand in Mumbai after greening of roofs and walls (13).

Cooling due to evapotranspiration is heavily dependent on the availability of ground water. In dry climates, the cooling due to evapotranspiration is often offset by increased irrigation costs (14). Contrastingly, in presence of adequate amount of ground water, a single tree transpiring about 400litres of water daily can provide airconditioning efficiency of $20 \mathrm{~kW}$ (15). While shading and evapotranspiration are direct methods of coolings. vegetative elements cool the environment indirectly through carbon sequestration.

\subsection{Cooling Through Carbon Sequestration}

Urban trees fix and store carbon, thereby reducing the net amount of atmospheric carbon dioxide (16). While urban trees provide sequestering benefits of $\$ 13,701$ per annum in Lisbon, Portugal (17), 22.8 million tone Carbon/year is sequestered by urban trees in USA, amounting to monetary savings of $\$ 14,300$ (16). The Kerwa forest area, located close to Bhopal in India is a major carbon sink and is estimated to store about 19.5 thousand tons of above-ground carbon (18).

\section{Mental and Physical Benefits}

Urban greenery provides mental and physical benefits through:

\subsection{Reduced Stress Level and Health Benefits}

Visits to green areas have been associated with relaxation,proximity to nature, and have been linked with feelings of freedom, happiness, and unity with nature (19). "Contact with nature is hypothesized to help people restore from additional fatigue and stress"(20). Recovery form stress, physical illness and long-term behavioural changes have been propounded (21).

\subsection{Enhanced Quality of Life}

Roadside greenery has been associated with better usability of streets, and when accompanied with recreational amenities provides for resting spaces, and facilitates better social communication (22).However, reports from UK link increasing urban density with decreasing residential garden size (23)(24). Similar findings have been reported from the Indian city of Kozhikode where the economically affluent group exhibits an alarming tendency for updating technological standards at the cost of decrease in private green spaces (25). It is noteworthy to mention that residential gardens 
provide valuable habitat for endangered species of the wildlife, and have been described as UK's 'most important nature reserve' (24). Recently, species composition, floristic diversity, importance value, and spatial distribution of trees were investigated for 102 public housing estates in Hong Kong (26).Similarly, some notable research has been attempted in the cities of Bengaluru(27)(28), and Nagpur (29) in India.A databank of state wise street tree was recently prepared for the New York State, USA (30). Although the civic body in Chennai, India has initiated steps towards tree census (31), and the Indian Environment Ministry has recently proposed to conduct national level tree census (32), the city wise data bank is largely missing in Indian cities.

Table 1: Comparison between Global and Indian Research Investigating the Benefits of Urban Green Spaces

\begin{tabular}{|c|c|c|c|c|c|}
\hline & & Location & $\begin{array}{l}\text { Referenc } \\
\text { e }\end{array}$ & Location & $\begin{array}{l}\text { Referenc } \\
\text { e }\end{array}$ \\
\hline \multicolumn{2}{|c|}{ BENEFITS } & \multicolumn{2}{|c|}{ INTERNATIONAL } & \multicolumn{2}{|c|}{ INDIA } \\
\hline \multirow{13}{*}{ ENVIRONMENTAL } & \multirow{4}{*}{$\begin{array}{l}\text { Attenuation } \\
\text { atmospheric pollution }\end{array}$} & Hiroshima, Japan & (33) & Nagpur & (29) \\
\hline & & Serbia & (4) & Bengaluru & (5) \\
\hline & & Portland, USA & (34) & Gandhinagar & (9) \\
\hline & & Siena, Italy & (35) & & \\
\hline & \multirow{6}{*}{$\begin{array}{l}\text { Passive cooling of } \\
\text { environment }\end{array}$} & Fukuoka, Japan & (11) & \multirow[t]{6}{*}{ Mumbai } & \multirow[t]{6}{*}{ (13) } \\
\hline & & Sacramento, USA & (12) & & \\
\hline & & Singapore & (36) & & \\
\hline & & Serdang, Malaysia & (37) & & \\
\hline & & Melbourne, Australia & (38) & & \\
\hline & & Gotenborg, Sweden & (39) & & \\
\hline & \multirow{3}{*}{$\begin{array}{l}\text { Cooling through carbon } \\
\text { sequestration }\end{array}$} & USA & (16) & \multirow[t]{3}{*}{ Bhopal } & \multirow[t]{3}{*}{ (18) } \\
\hline & & Lisbon, Portugal & (17) & & \\
\hline & & 35 Cities in China & (40) & & \\
\hline \multirow{6}{*}{$\begin{array}{l}\text { PHYSICAL \& } \\
\text { MENTAL }\end{array}$} & \multirow{3}{*}{$\begin{array}{l}\text { Reduced stress level and } \\
\text { physical health benefits }\end{array}$} & UK & (41) & & \\
\hline & & $\begin{array}{l}\text { Utrecht, Rotterdam, } \\
\text { Arnhem, den Bosch in } \\
\text { Netherlands }\end{array}$ & (20) & & \\
\hline & & $\begin{array}{l}\text { Dusseldorf and Cologne } \\
\text { in Germany }\end{array}$ & $(42)$ & & \\
\hline & \multirow[t]{3}{*}{ Enhanced quality of life } & New York State, USA & (30) & Bengaluru & $(27)(28)$ \\
\hline & & Hong Kong, China & (26) & \multirow[t]{2}{*}{ Nagpur } & \multirow[t]{2}{*}{ (29) } \\
\hline & & $\begin{array}{llll}\text { Cologne } & \& & \text { Berlin } & \text { in } \\
\text { Germany } & & & \end{array}$ & (22) & & \\
\hline \multirow[b]{2}{*}{ SOCIAL } & \multirow{2}{*}{$\begin{array}{l}\text { People's perception and } \\
\text { preferences }\end{array}$} & Europe & (43) & & \\
\hline & & $\begin{array}{llll}\text { Cologne } & \& & \text { Berlin in } \\
\text { Germany } & & & \\
\end{array}$ & (22) & & \\
\hline \multirow{4}{*}{ ECONOMIC } & \multirow{3}{*}{$\begin{array}{l}\text { Increase in real estate } \\
\text { prices }\end{array}$} & Research Triangle, USA & $(44)$ & Chandigarh & $(45)(7)$ \\
\hline & & Zhuhai, China & (46) & Mumbai & $(47)$ \\
\hline & & Taiwan & (48) & Chandigarh & (49) \\
\hline & Social forestry & Scandinavia \& Japan & (50) & Thane & (51) \\
\hline
\end{tabular}

Note: A number of other global research studies are available, but since the objective of this study is to provide a broad overview, only few examples have been cited here

\section{Social Benefits}

Besides providing spaces for leisure activities, green spaces encourage social well-being through social integration, engagement and participation(52). They pacify the fast pace of urban life for adults while providing natural spaces for children to play in. Access to green spaces within 15 min walking distance has been recommended in Europe by the European Environment Agency (43). However, neighbourhoods with predominant population of racial minorities and socioeconomically disadvantage groups might have lesser access to parks (53). 


\section{Economic Benefits}

\subsection{Increase in Real Estate Prices}

Proximity to urban parks and open spaces increases desirability of houses while adding to the aesthetic appeal of the property. Adjacency of forest block was found to increase housing price by more than $\$ 8000$ in Research Triange, USA (44). Proximity to Sukhnalake in Chandigarh and Leisure Valley chain of green spaces in India increased the housing prices by $10 \%$ and $2 \%$ respectively (7). The impact of environmental amenities on property prices was investigated in Mumbai(47). The Contingent Value Method has been used to study the nonmarket economic valuation of environmental amenities in Chandigarh, India (49), and used to estimate the nonmarket leisure value of an urban greening project in Zhuhai, China (46). Residents and domestic tourists in Chandigarh, India exhibited a willingness to pay for maintenance, thus highlighting an avenue for income generation (45).

\section{Other Benefits}

Practicing of social forestry has been strongly advocated by the Indian government for enabling rural households with better economic and livelihood prowess. Social forestry provides employment opportunities for unskilled workers and has been explored effectively in the state of Maharashtra in India (51).

\section{Inference}

The following inferences have been drawn from Table 1 which summarises the research conducted on urban greenery in India and elsewhere-

Research on the role of green spaces in urban India remains restricted to a few metropolitan cities. While relatively more study has been devoted to examine the effect of greenery on atmospheric pollution, the passive cooling effect of vegetation and sequestering of carbon remain largely unexplored. Urban green spaces provide an economically feasible method of cooling especially for the urban poor, who are deprived of material sources to overcome heat stress.

Most of the studies related to physical and mental health benefits due to green spaces appear to be concentrated in the Western world. A lot of importance has been attached to the role of open spaces in daily lives in Europe. No study has been found on this issue in the Indian context.

Deficiency of development funds and lack of adequate recognition to the importance of green areas may have contributed to the lack of studies investigating the social benefits arising from green spaces. Green spaces and open areas are an essential requirement for a prosperous community life. The multi-cultural heritage and diversity of communities in India should be strengthened with better social cohesionthrough intelligently designed urban open spaces.

Some research has focused on economic gains due to green spaces in the Indian cities of Chandigarh and Mumbai. However, devaluation of urban green cover and lack of public participation necessitate future studies in urban India which can be used to convince city dwellers about the intangible and tangible benefits of green spaces. India has produced some impressive studies in the field of social forestry which aims to empower rural households with better avenues for self-sustenance. Such practices can be emulated in other developing countries for better rural empowerment.

\section{References}

[1] Kabisch, N., Qureshi, S., \& Hasse, D. (2015). Human-environment interactions in urban spaces- A systematic review of contemporay issues and prospects for future research. Environmental Impact Assessment Review, 50, 25-34.

https://doi.org/10.1016/j.eiar.2014.08.007

[2] Nowak, D. J. (1994). Air pollution remoaval by chicago's Urban Forest. In E. G. McPherson, D. J. Nowak, \& R. A. Rowntree, Chicago's urban Forest Ecosystem: Results of the Chicago Urban Forest Climate Project (pp. 63-83). Pennsylvania: US Department of agriculture-Northeastern Forest Experiment Station.

[3] Akbari, H., Pomerantz, M., \& Taha, H. (2001). Cool surfaces and shade trees to reduce energy use and improve air quality in urban areas. Solar Energy, 70 (3), 295-310. 
https://doi.org/10.1016/S0038-092X(00)00089-X

[4] Kocic, K., Spasic, T., Urosevic, M. A., \& Tomasevic, M. (2014). Trees as natural barriers agaisnt heavy metal pollution and their role in the protection of cultural heritage. Journal of Cultural Heritage, 15, 227-233. https://doi.org/10.1016/j.culher.2013.05.001

[5] Chaturvedi, A., Kamble, R., Patil, N. G., \& Chaturvedi, A. (2013). City-forest relationship in Nagpur: One of the greenest cities of India. Urban Forestry \& Urban Greenery, 12, 79-87.

https://doi.org/10.1016/j.ufug.2012.09.003

[6] Vailshery, L. S., Jaganmohan, M., \& Nagendra, H. (2013). Effect of street trees on microclimate and air pollution in a tropical city. Urban Forestry \& Urban Greening, 12, 408-415.

https://doi.org/10.1016/j.ufug.2013.03.002

[7] Sustainability Outlook. (2012, March 13). Open Spaces for Urban Sustainability. Retrieved September 24, 2015, from http://sustainabilityoutlook.in/content/open-spaces-urban-sustainability

[8] Chaudhry, P., Sharma, M. P., Singh, G., \& Bansal, A. (2013). Vauation of urban environmental amenities in developing countries: A case study from Chandigarh, India. Global Journal of Science Frontier Research-Environment \& Earth Science, XII (II), 1-13.

[9] Garg, A., Shukla, P. R., Bhattacharya, S., \& Dadhwal, V. K. (2001). Sub-region (dstrict) \& sector level SO2 \& NOx emissions for India: assessment of inventories \& mitigation flexibility. Atmospheric Environment, 35, 703-713. https://doi.org/10.1016/S1352-2310(00)00316-2

[10] Padmavathi, P., Cherukuri, J., \& Reddy, M. A. (2015). Ambient air pollutant levels in the vicinity of NTTPS thermal power plant. IOSR Journal of Environmental Science, Toxicology and Food Technology (IOSR-JESTFT), 9 (2), 56-60.

[11] Bornstein, R. D. (1968). Observations of the Urban Heat Island effect in New York City. Journal of Applied Meteorology, 7, 575-582. https://doi.org/10.1175/1520-0450(1968)007<0575:OOTUHI>2.0.CO;2

[12] Hoyano, A. (1988). Climatological uses of plants for solar control and the effects on the thermal environment of a building. Enery and Buiding, 11, 181-199.

https://doi.org/10.1016/0378-7788(88)90035-7

[13] Akbari, H., Kurn, D. M., Bretz, S. E., \& Hanford, J. W. (1997). Peak power and cooling energy savings of shade trees. Energy and Buildings, 25, 139-148. https://doi.org/10.1016/S0378-7788(96)01003-1

[14] Alexandri, E., \& Jones, P. (2008). Temperature decreases in an urban canyon due to green walls and green roofs in diverse climates. Building and Environment, 43, 480-493.

https://doi.org/10.1016/j.buildenv.2006.10.055

[15] McPherson, E. G., Simpson, J. R., \& Livingston, M. (1989). Effects of three landscape treatments on residential energy and water use in Tuscon, Arizona. Energy and Buildings, 13, 127-138.

https://doi.org/10.1016/0378-7788(89)90004-2

[16] Yu, C., \& Hien, W. N. (2006). Thermal benefits of city parks. Energy and Buildings, 38, 105-120. https://doi.org/10.1016/j.enbuild.2005.04.003

[17] Pokorny, J. (2001). Dissipation of solar energy in landscape-controlled by management of water and vegetation. Renewable Energy, 24, 641-645. https://doi.org/10.1016/S0960-1481(01)00050-7

[18] Cameron, R. W., Blanusa, T., Taylor, J. E., Salisbury, A., Halstead, A. J., Henricot, B., et al. (2012). The domestic garden - Its contribution to urban green infrastructure. Urban Forestry and Urban Greening, 11, 129-137. 
https://doi.org/10.1016/j.ufug.2012.01.002

[19] Nowak, D. J., \& Crane, D. E. (2002). Carbon storage and sequestration by urban trees in the USA. Environmental Pollution, 116, 381-389. https://doi.org/10.1016/S0269-7491(01)00214-7

[20] Soares, A. L., Rego, F. C., McPherson, E. G., Simpson, J. R., Peper, P. J., \& Xiao, Q. (2011). Benefits and costs of street trees in Lisbon, Portugal. Urban Forestry and Urban Greening, 10, 69-78.

https://doi.org/10.1016/j.ufug.2010.12.001

[21] McHale, M. R., McPherson, E. G., \& Burke, I. C. (2007). The potential of urban tree plantings to be cost effective in carbon credit markets. Urban Forestry \& Urban Greening, 6, 49-60.

https://doi.org/10.1016/j.ufug.2007.01.001

[22] Dwivedi, P., Rathore, C. S., \& Dubey, Y. (2009). Ecological benefis of urban forestry: The case of Kerwa Forest Area (KFA), Bhopal, India. Applied Geography, 29, 194-200. https://doi.org/10.1016/j.apgeog.2008.08.008

[23] Chiesura, A. (2004). The role of urban parks for the sustainable city. Landscape and Urban Planning, 68, 129-138. https://doi.org/10.1016/j.landurbplan.2003.08.003

[24] de Vries, S., van Dillen, S. M., Groenewegen, P. P., \& Spreeuwenberg, P. (2013). Streetscape greenery and health: Stress, social cohesion and physical activity as mediators. Social Science and Medicine, 94, 26-33. https://doi.org/10.1016/j.socscimed.2013.06.030

[25] Velarde, M. D., Fry, G., \& Tveit, M. (2007). Health effects of viewing landscapes-Landscape types in environmental psychology. Urban Forestry \& Urban Greening, 6, 199-212.

https://doi.org/10.1016/j.ufug.2007.07.001

[26] Weber, F., Kowarik, I., \& Saumel, I. (2014). A walk on the wild side: Perceptions of roadside vegetation beyond trees. Urban Forestry and Urban Greening, 13, 205-212. https://doi.org/10.1016/j.ufug.2013.10.010

[27] Whitford, V., Ennos, A. R., \& Handley, J. F. (2001). "City form and natural process"-indicators for the ecological performanc eof urban areas and their application to Merseyside, UK. Landscape \& Urban Planning, 57 (2), 91-103. https://doi.org/10.1016/S0169-2046(01)00192-X

[28] Gangopadhyay, K., \& Balooni, K. (2012). Technological infusion and the change in private, urban green spaces. Urban Forestry and Urban Greening, 11, 205-210. https://doi.org/10.1016/j.ufug.2011.12.003

[29] Zhang, H., \& Jim, C. Y. (2014). Contributions of landscape trees in public housing estates to urban biodiversity in Hong Kong. Urban Forestry \& Urban Greening, 13, 272-284. https://doi.org/10.1016/j.ufug.2013.12.009

[30] Jaganmohan, M., Vailshery, L. S., Gopal, D., \& Nagendra, H. (2012). Plant diversity and distribution in urban domestic gardens and apartments in Bangalore, India. Urban Ecosystem, 15, 911-925.

https://doi.org/10.1007/s11252-012-0244-5

[31] Sudha, P., \& Ravindranath, N. H. (2000). A study of Bangalore urban forest. Landscape and Urban Planning, 47, 4763. https://doi.org/10.1016/S0169-2046(99)00067-5

[32] Cowett, F. D., \& Bassuk, N. L. (2014). Statewise assessment of street trees in New York State, USA. Urban Forestry \& Urban Greening, 13, 213-220.

https://doi.org/10.1016/j.ufug.2014.02.001 
[33] Environmentalists welcome Chennai Corporation's plan to conduct tree census

[34] Environment ministry proposes India's first tree census

[35] Dinnie, E., Brown, K. M., \& Morris, S. (2013). Community, cooperation and conflict: Negotiating the social wellbeing benefits of urban greenspace experiences. Landscape \& Urban Planning, 112, 1-9.

https://doi.org/10.1016/j.landurbplan.2012.12.012

[36] Barbosa, O., Tratalos, J. A., Armsworth, P. R., Davies, R. G., Fuller, R. A., Johnson, P., et al. (2007). Who benefits from access to green space? A case study from Sheffield, UK. Landscape \& Urban Planning, 83, 187-195.

https://doi.org/10.1016/j.landurbplan.2007.04.004

[37] Dai, D. (2011). Racial/ethnic and socioeconomic disparities in urban green space accessibility: Where to intervene? Landscape and Urban Planning, 102, 234-244.

https://doi.org/10.1016/j.landurbplan.2011.05.002

[38] Wolfe, M. K., \& Mennis, J. (2012). Does vegetation encourage or suppress urban crime? Evidence from Philadelphia, PA. Landscape and Urban Planning, 108, 112-122.

https://doi.org/10.1016/j.landurbplan.2012.08.006 